\title{
A komposztérettség és meghatározásának módszerei - Szemle -
}

\author{
KovÁcs Dénes és FÜLEKY György
}

Szent István Egyetem, Mezőgazdaság- és Környezettudományi Kar, Környezettudományi Intézet, Talajtani és Agrokémiai Tanszék, Gödöllő

\section{Bevezetés}

A komposztálás egy olyan ember által irányított folyamat, amely során a szervesanyagok a talaj-mikroorganizmusok segítségével levegö jelenlétében lebomlanak, átalakulnak, majd belőlük az érés során nagy molekulájú huminvegyületek épülnek fel (DUNST, 1991), a hulladék szerves frakciója humusszá és ennek különböző formáivá alakul (GolUEKE, 1977; SCHNITZER \& KAHN, 1987). Ez az aerob biológiai degradáció a különféle szerves hulladékok biológiai és kémiai oxidációja, amely a szerves anyagok természetes bomlásának gyors formája. Fontos fizikokémiai változások történnek a bomlás során, amelyek a térfogatot, tömeget, térfogattömeget és a szubsztrát víztartalmát befolyásolják (ALBURQUERQUE et al., 2004).

A komposztálás trágyázószer és talajjavító anyag (CIAVATTA et al., 1991; LOPEZ-REAL \& BAPTISTA, 1996) készítésére alkalmas eljárás. A tápanyagok körforgása és a szervesanyag-tartalom, illetve a talaj fizikai tulajdonságainak fenntartása, megőrzése szempontjából fontos és egyben olcsó technológia (SHIRALIPOUR et al., 1992; MCCONNELl et al., 1993; GUISQUIANI et al., 1995) alkalmazásával az emisszió is csökkenthető (IANNOTTI et al., 1994).

\section{Komposztérettség}

A komposzt érését a következő folyamatok kísérik: a szervesanyag-tartalom csökken és stabilizálódik, csökken a teljes szén $\left(C_{t}\right)$ mennyisége, a vízoldható fémtartalom, az ammónium-N tartalom, metoxi- és alkilcsoportok száma, növekszik a hamutartalom, a nitrát + nitrit- $\mathrm{N}$ tartalom, a huminsav (HA) tartalom és a huminsav/fulvosav (HA/FA) arány. Növekszik továbbá a kationcsere kapacitás (CEC; T-érték), az összes $\mathrm{N}$-tartalom $\left(\mathrm{N}_{\mathrm{t}}\right)$, a huminsav széntartalma $\left(\mathrm{C}_{\mathrm{HA}}\right)$, a lignintartalom, illetve a fenolos, aromás, karboxil és a metoxil csoportok száma, továbbá a komposztálás végére megszünik a fitotoxicitás (RIFFALDI et al., 1986; INBAR et al., 1990).

Postai cím: KOVÁCS DÉNES, SZIE MKK Környezettudományi Intézet, Talajtani és Agrokémiai Tanszék, 2103 Gödöllő, Páter K. u. 1.E-mail: k.denes@profikomp.hu 
Az érettség minősítése a komposzt alkalmasságának meghatározása a felhasználás szempontjából, ami kapcsolatban van a komposztálási folyamattal (BREWER \& Sullivan, 2001). A megfelelőség számos tényezőtől függ, mint például a lebomlás foka, a növekedési potenciál, (LEE, 1977; LYNCH, 1977; DEVLEESCHAUwER et al., 1981) a fitotoxikus összetevők - mint az ammónia, a fenolsav és a volatilizálható szerves savak - szintje (ZUCCONNI et al., 1981; JOURDAN, 1988; MANIOS, 1989; IANOTTI et al., 1993; IANOTTI, 1994; KIRCHMANN \& WIDÉN, 1994; BREWER \& SULLIVAN, 2003).

A komposzt érettségének és instabilitásának szemléltetésére számos vizsgálat folyt (SEPA 1997; REINIKAINEN \& HERRANEN, 2000; ITÄVAARA et al., 2002). Ilyen vizsgálatok például a komposztban lévő bontható és a rezisztens szerves anyagok mennyiségének meghatározása, a redox potenciál változás, vagy a gombák (Chaetomium gracilis) növekedésének mérése, a keményítő teszt (GOLUEKE, 1977), illetve az $\mathrm{N}_{\mathrm{t}}$ tartalom (HARADA et al., 1981; IANOTTI et al., 1994; HADAS \& PORTNOY, 1994, 1997), a hidrolizált N mennyiségének (SPOHN, 1978; FinSTEIN \& MiLLER, 1985), a redukáló cukor széntartalom és a $C_{t}$ arányának meghatározása (INOKO et al. 1979), vagy a papírkromatográfiás eljárásokkal végzett tesztek (INOKO, 1979; INOKO \& FUJUWARA, 1979). A hömérséklet, az ammónium, a vízoldható $\mathrm{Cu}, \mathrm{Zn}$ és a fitotoxicitás paraméterek mérése egyszerü eljárás, de a komposztérettséget nehéz meghatározni kizárólag ezek által. A komposztérettség és a komposztérettségi indexének meghatározásához mikrobiológiai paraméterekkel történő kiegészítést javasolnak úgy, mint mikrobaszám, oxigén felvétel sebessége, ATP-tartalom és a dehidrogenáz aktivitás meghatározása (TiQUiA, 2002). A nedvességtartalom, a $\mathrm{C}_{\mathrm{t}}$, a humuszanyagok (HA, FA), a foszfor-, a kálium-, a nehézfém-, és a sótartalom, a víztartóképesség, a térfogattömeg és a patogének mérése is használatos az érettség meghatározásához (ZUCCONNI et al.,1981; BLANCO \& ALMENDROS, 1994; OlIVEIRA et al. 2002; KÖRNER et al., 2003). Az érettségi paraméterek közül a legfontosabbak a vízoldható szén/szerves nitrogén $\left(\mathrm{C}_{\mathrm{W}} / \mathrm{N}_{\text {org }}\right)$, CEC (T-érték), CEC/szerves szén $\left(\mathrm{C}_{\mathrm{org}}\right)$ és a csírázási arány, kisebb valószínüséggel a $\mathrm{C} / \mathrm{N}$ és az $\mathrm{NH}_{4} / \mathrm{NO}_{3}$ arány szintén elfogadható.

Amennyiben a komposzt nem kellőképpen érett, akkor nem alkalmas annak a célnak a betöltésére, amire szánják. Még a termofil fázisban lévő, de már higiénikus komposzt talajrehabilitációs, mulcsozási célra felhasználható, de érzékeny kultúrák tápanyag és szervesanyag-pótlására nem alkalmazható, mert a sótartalma, a pHértéke, az ammóniumtartalma nagy, így jelentős a csírázásgátló hatása és növekedési depressziót okoz.

\section{Komposztstabilitás}

A stabilitás gyakorlati szempontból fontos fogalom, amely hasonló az érettséghez és elsősorban a mechanikai-biológiai hulladékkezelés hatékonyságánál használják. A stabilitás leírható a mikrobiális aktivitás fokaként (BUTLER et al., 2001), illetve lehet a komposztálás alatt bekövetkezett szervesanyag dekompozíciónak a foka (THE COMPOSTING ASSOCiATION, 2001), vagy állapota (STENTIFORD, 2002), 
amely összefüggésben van a megmaradt szerves összetevők típusával és az ebből származó biológiai aktivitással (CCQC, 2001). Stabilnak mondható a komposzt annál a pontnál, ahol az oxigénfogyasztás lecsökkenése nem teszi lehetővé az anaerob, vagy szaghatást kiváltó feltételek kialakulását. Ezek ismerete a komposzt tárolásakor vagy felhasználásakor fontos (HAUG, 1993). Stabilnak mondható a komposzt azon a ponton, ahol a degradálható szubsztrát mennyisége lecsökkent, vagy lebomlott (ZuCCONNI \& DE BERTOLDI, 1987; LASARIDI \& STENTIFORD, 1996), így annak nincs hatása a teljes dekompozícióra (MCADAMS \& WHITE, 1996). Ez meghatározza azt a pontot, amit elért az anyag a dekompozíció folyamatában és egy fokozatot mutat, amivel az átalakulás szintjére lehet következtetni. (LASARIDI \& STENTIFORD, 1996; PAS 100, 2002). A stabilitást legjobban definiáló paraméterek a vízoldható- és fulvosav szén $\left(\mathrm{C}_{\mathrm{W}}\right.$ és $\left.\mathrm{C}_{\mathrm{FA}}\right)$ frakciók, a lignin koncentrációval együtt, illetve respirometriás értékek és a szerves anyag összetétele (CHEN et al.,1996). Azok az érettségi indexek vagy paraméterek, melyek közvetlen kapcsolatban vannak a komposztban található könnyen lebontható szerves anyag mért értékeivel, felhasználhatóak a komposzt stabilitásának meghatározására - a könnyen degradálható frakció alacsony értéke nagymértékü biológiai stabilitást jelez (ADANI et al., 2004).

Amennyiben a komposzt nem stabil, akkor az utókezelés (rostálás), tárolás és felhasználás során megváltoznak egyes tulajdonságai (pl. melegszik, büzös szagokat termel, penészesedik). Egy stabil komposzt már tekinthető szubsztrát-érettnek, szubsztrát komposztnak, ami lehetővé teszi például ültetőközegként történő felhasználását. Az érettség eléggé tág meghatározás, mert valamilyen felhasználás szempontjából tekinthető érettnek az anyag, ami lehet rekultiváció, talajjavítás, szántóföldi-, kertészeti felhasználás, míg a stabil komposzt vizsgált paraméterei egy bizonyos értékhatárt elértek függetlenül a kiindulási nyersanyagtól, a folyamat állapotától vagy az alkalmazott technológiától.

Az érettségi szintek, illetve stabilitási fokok meghatározására számos tudományos kísérletet végeztek, aminek értékelését szeretnénk tematikusan összefoglalni.

\section{A komposztérettség vizsgálatára alkalmazott fizikai módszerek}

A fizikai jellemzők, mint a színváltozások (SUGAHARA et al., 1979), a szag és a hőmérséklet általános képet mutat a komposztálás állapotáról, de kevés információt ad az érettségi fokról.

A Fourier-transzformációs infravörös spektroszkópia (FTIR) - amely széles spektrális tartományban gyüjt egyidejüleg adatokat - spektruma a komposztálás alatt a poliszacharidok erőteljes lebomlását és az aromás polimerek szintézisét mutatta. A spektrum a HA minőségi változását is jelzi, különösen az aromás részek és a karboxil ionok növekedtek (INBAR et al.,1990).

A mágneses magrezonancia (NMR) a mágneses mezőbe helyezett anyagban fellépő azon jelenség, melynek során egy másik, rádiófrekvenciás (elektro)mágneses térrel besugározva azt bizonyos frekvenciákon - azaz „rezonanciaszerüen” - elnyeli. Molekulába, oldatba vagy kristályrácsba ágyazott részecske esetében a külső 
mágneses tér az elektronfelhőt polarizálja, ezáltal az a gyengített mágneses teret érzékeli. A különbözőképpen árnyékolt részecskék különböző frekvenciájú fotonokat nyelnek el, illetve az adott frekvenciájú fotont különböző külső mágneses térnél abszorbeálják.

A ${ }^{13} \mathrm{C}$ NMR spektrum a pszeudohumusz anyagok lebomlását, az alifás széntartalom csökkenését és az aromás-, karboxil- és karbonil-széntartalom növekedését mutatja, amely a humuszanyagok részleges újjáalakulására enged következtetni (CASTALDIA et al., 2005).

A közeli infravörös spektroszkópia (NIRS) az elektromágneses spektrum közeli infravörös tartományát (800-2 $500 \mathrm{~nm}$ ) használja. A NIRS technikával mérhető spektrumok egyedi jelet, ún. hullámprofilt adnak, fontos biokémiai információkat nyújtva a funkciós csoportok (-CH, -OH, -NH kémiai kötések) karakteréről és számáról, illetve a mérés során egy precíz kémiai ujjlenyomat képezhető a szerves anyagokról (BEN-DOR et al., 1997). A NIRS széleskörüen alkalmazott eljárás a hulladék dekompozíciós folyamatainak - mint például a komposztálás - elemzésére (JOFFRE et al., 1992; GILlON et al., 1993; COUTEAUX et al., 1995), különösen a cellulóz bomlásának analízisére (HARTMANN \& APPEL, 2006). BEN-DOR és munkatársai (1997) szoros korrelációt mutatott ki a OH és a C-H csoportok mennyisége (kombinálva higroszkópos vízzel, keményítővel, cellulózzal és ligninnel) és a komposztálás ideje között. A NIRS használható számos kémiai összetevő kalibrálására, mint a $\mathrm{C}_{\mathrm{t}}$, a $\mathrm{C}_{\text {org }}$ a $\mathrm{C} / \mathrm{N}$ arány és a $\mathrm{pH}$ (SUEHARA et al., 2001; MALLEY et al., 2005). $\mathrm{Az}$ abszorpció által kimutathatók a $\mathrm{C}-\mathrm{H}, \mathrm{N}-\mathrm{H}$ és O-H csoportok minden szerves összetevőben. INBAR és munkatársai (1989) szerint a NIRS kalibrálható az érettségi index használatával és létrehozható egy NIRS és kémiai adatbank, ami biztosíthatja az érettség meghatározását. A komposztban újonnan kialakult szerves anyagok természete különbözik a talaj humusztól, így számos vita alapja, hogy melyik módszer alkalmazható sikeresen a komposztvizsgálatokhoz (STEVENSON, 1982).

A thermogravimetria (TG; tömegváltozás a $\mathrm{T}$ függvényében) és a differenciált scanning kalorimetria (DSC; hőmérséklet-emelkedésre bekövetkezö kristályszerkezet és halmazállapot változás hatására felszabaduló hőmennyiség, amivel azonosítható az anyagok kémiai szerkezete). Ez a két leggyakrabban használt technika, mely egyszerü, gyors, ismételhető és információt szolgáltat a höstabilitásról a minta elökészítése nélkül (BLANCO \& ALMENDROS, 1994; DELL'ABATE et al., 2000).

A Dewar módszerrel a komposztban termelődő hő alapján határozható meg annak érettsége. A mintát hővisszatartó edénybe teszik és a képződő hőt mérik a maximum tíznapos periódus alatt. A módszer olcsó és egyszerủen kivitelezhető (NORDTEST REPORT, 1998), de nem reprodukálható (WEPPEN, 2002), a komposztálás meghatározott fázisaiban alkalmazható, nem ajánlott általánosságban. A Dewar tesztet a Német Környezetvédelmi Minisztérium hivatalos szabványként fogadta el az érettség megállapításához 1984-ben az 1982-es szennyvíziszap rendelet után (LAGA, 1984). Az önhevülési teszt kapcsolatban van a csírázásgátlási teszttel, sokkal inkább megfelelő a végtermék stabilitásának/érettségének meghatározására. A komposzt akkor tekinthető érettnek, ha a hőmérséklete lecsökkent és forgatás hatására sem mutat reakciót (STICKELBERGER, 1975), a környezeti hőmérséklet értékét közelíti (ALBURQUERQUE et al., 2005). 
1. táblázat

A komposztérettségi fokai a BKG (Bundesgütegemeinschaft Kompost Szövetségi Komposztminőség-biztosítási Társaság) szerint

\begin{tabular}{|l|c|}
\hline Érettségi fok & Hőmérsékleti maximum, ${ }^{\circ} \mathrm{C}$ \\
\hline I. & $60-70$ \\
II. & $50-60$ \\
III. & $40-50$ \\
IV. & $30-40$ \\
V. & $20-30$ \\
\hline
\end{tabular}

A komposztok osztályozásánál az érett $\left(0-5^{\circ} \mathrm{C}\right)$, érés alatt lévő $\left(5-15^{\circ} \mathrm{C}\right)$ és az aktív (15-25 $\left.{ }^{\circ} \mathrm{C}\right)$ komposzt különböztethetö meg. Néhány komposzt magasabb, mint $25^{\circ} \mathrm{C}$-ra hevült a Dewar edényben, valószínüleg extrém mértékben éretlen és fitotoxikus.

A BGK (Bundesgütegemeinschaft Kompost) az 1. táblázatban feltüntetett érettségi fokokat határozta meg. A hőmérséklet meghatározása azonban a prizmában nem használható a komposzt érettségi fokának megállapításához.

Következtetésünk a fizikai módszerekkel végzett vizsgálatok eredményeinek függvényében, hogy a Dewar teszt egyszerü, olcsó és elfogadott, a thermogravimetria (TG) és a differenciált scanning kalorimetria (DSC) pedig egyszerü, gyors és ismételhető. Az FTIR, az NMR és a NIRS számos érettséget mutató faktor változását mutatja nagy precizitással. A komposzt és a talaj szerves (humusz) anyagai közötti különbség miatt azonban továbbra is vita forrása, hogy melyik módszer alkalmazható eredményesen a komposztvizsgálatokhoz (STEVENSON, 1982). A szín és a szag nem mutatja meg egyértelmüen a komposztérettséget.

\section{A komposztérettség vizsgálatára alkalmazott biológiai módszerek}

Az érettségi fok kifejezhető biológiai módszerekkel, ami magában foglalja a csírázásgátló hatás vizsgálatát, a csírázási és a növény-növekedési erélyére vonatkozó, illetve a gyökérhossz vizsgálatot is. Számos növénynövekedési vizsgálatot végeztek a komposztérettség meghatározásához. ZUCCONNI és DE BERTOLDI (1987) vizsgálati eredményi alapján azonban a zsázsamag csírázása és a napraforgó fiziológiai paraméterei közül egyik sem adott megbízható értéket. A gyökérnövekedés és a növény tömege érzékeny a komposzt érettségére. Az érett és félérett komposzt közötti különbség $(\mathrm{p}<0,04)$ sokkal jelentősebb volt, mint az érett komposzt és a kontrol közötti különbség $(\mathrm{p}<0,10)$. A csírázási eredmények azt mutatják, hogy a komposztban termelődő $\mathrm{CO}_{2}$-nak nagyon kicsi, vagy nincs is szignifikáns hatása a

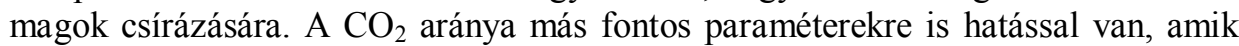
befolyásolják a növényi növekedést, mint például a volatilis zsírsav (VFA; légnemü halmazállapotba alakuló zsírsav), vagy az ammónia mennyisége, illetve a $\mathrm{C} / \mathrm{N}$ arány. 
A respiráció a mikrobiális aktivitás megbízható indexeként vehető figyelembe (NANNIPIERI et al., 1990). A respirometrikus paraméterek alapján a komposztstabilitás nő az idő elörehaladtával (LIMA \& FERRER, 2005). Az érettség növekedésével kevesebb a mikroorganizmusok számára hasznosítható szubsztrát és az oxigénfogyasztás aránya is csökken (FINSTEIN et al., 1986; DERIKX et al., 1990; IANNOTTI et al., 1993; LASARIDI et al., 1996). A komposzt érettsége, illetve stabilitása meghatározható az oxigénfogyasztás és a széndioxid termelés által, melyek jól jelzik a jelenlévő degradálható szerves anyag mennyiségét és fordított összefüggésben vannak a stabilizációval (ZUCCONNI \& DE BERTOLDI, 1987).

A mikroorganizmusok légzésintenzitása $\left(\mathrm{O}_{2}\right.$ igény és $\mathrm{CO}_{2}$ termelés aránya) akkor a legnagyobb, amikor nagy a biológiailag bontható szerves anyag százaléka, (HuE \& LiU, 1995) míg a respirációs arány alacsony, ha abból kevés van. Az érett komposzt respirációs aránya szignifikánsan alacsonyabb, mint a kiindulási nyersanyagé (GolUEKE, 1977; RIBALDA et al., 1987). A légzésaktivitás fontos paraméter a komposztstabilitás meghatározásához és fontos tényező az anyag érettségének becsléséhez is. A respirometriás megközelítés a gyakorlatban sikeresen alkalmazott a komposztminőség meghatározására több országban is: Olaszország, Németország, Ausztria, UK, USA, ahol e módszerek nemzetközileg is kódoltak (ASTM, 1996; AMERIKAI KOMPOSZT TANÁCS, 1997). MATHUR (1982) szerint azonban az összehasonlításokat a szervesanyag-tartalomra vonatkoztatva kellene megadni és nem a szárazanyagra, mert különben nem jelzi megbízhatóan azérettséget.

HUE és LIU (1995) szerint a 2-3 napos inkubációs teszt átlagát alapul véve a komposztérettség határértéke $120 \mathrm{mg} \mathrm{CO}{ }_{2} \cdot(\mathrm{kg} \cdot \mathrm{h})^{-1}$.

PALETSKI és YOUNG (1995), illetve LASARIDI és munkatársai (2000) szerint az $\mathrm{O}_{2}$ felvételen alapuló respirometria a legjobb módszer a komposzt minta stabilitásának a meghatározására, mivel közvetlenül az aerob mikrobiális populáció anyagcsere-aktivitásáról ad információt.

KovÁCS és munkatársai (2007) eredményei alapján a szennyvíziszap-komposzt nyersanyag hét napos összegzett $\mathrm{O}_{2}$-fogyasztása majdnem kétszerese a két hónapig kezelt anyag $\mathrm{O}_{2}$-fogyasztásának. A második naphoz tartozó pillanatnyi $\mathrm{CO}_{2}$ termelés sebességének (v2d) értékei alapján a kezeletlen (0 hónap) v2d értéke kétszerese a hatodik hónaphoz tartozó v2d értéknek. Eredményeik alapján a második naphoz tartozó pillanatnyi $\mathrm{O}_{2}$-fogyasztás és $\mathrm{CO}_{2}$-termelés sebességével jellemezhető jobban a komposztok stabilizációs folyamata. A mérési módszer hátránya, hogy költséges, időigényes, szakmai felkészültséget kíván, így komposztáló telepek esetében rutinszerü elemzésre nem alkalmazható. $\mathrm{Az} \mathrm{O}_{2}$-fogyasztás és $\mathrm{CO}_{2}$-termelés fenti módszerrel történő mérésének a komposztok és komposztálási technológiák minősítésében lehet jelentősége.

$\mathrm{Az}$ önhevülési teszt eredményeit összehasonlítva az $\mathrm{O}_{2}$-felvétel és a $\mathrm{CO}_{2}$ termelés maximális értékeivel megállapítható, hogy önhevüléssel a komposztálás elején lehet leginkább különbséget tenni az érettségi fokok között, a komposztálás vége felé ennél érzékenyebb technikát érdemes alkalmazni. A komposztok hőmérséklet, $\mathrm{O}_{2}$-fogyasztás, $\mathrm{CO}_{2}$-termelés értékei között szoros összefüggés mutatható ki a korrelációs értékek alapján (KovÁCS et al., 2007). 
A dinamikus légzésintenzitás index (DRI; dinamikus vizsgálati módszer) jellemzően arra az óránkénti átlagos oxigénmennyiségre vonatkoztatott számérték, amely a vizsgált minta intenzív bomlási fázisában a minta biológiailag lebontható szervesanyag-tartalmának mikrobiológiai átalakulása során felhasználásra kerül $\left(\mathrm{mg} \mathrm{O}_{2} \cdot(\mathrm{kg} \text { szervesanyag } \cdot \mathrm{h})^{-1)}\right.$. Ez a módszer sikeresen használható a biológiai aktivitás mérésére, mivel párosítani képes a biológiai stabilitás definicióit és mérhető vele az oxigén felvétel (ADANI et al., 2004, 2006). A DRI értéke kétféleképpen határozható meg, a maximum értékből, vagy a 24-órás mérésből. Kész komposzt esetében a DRI $1,00 \mathrm{mg} \mathrm{O} \mathrm{O}_{2} \cdot(\mathrm{kg} \mathrm{VS} \cdot \mathrm{h})^{-1}$ alatt van $(\mathrm{CEC}, 2001)$. (A VS: volatilis szubsztrát - a légnemü halmazállapotba átalakuló szervesanyag.)

A biológiai oxigén igény $\left(\mathrm{BOI}_{5}\right)$ a folyadékban levő biológiailag lebontható szerves anyagok mikrobiális (bakteriális) lebontásához szükséges ötnapos oxigénfogyasztást jelenti, amiből következtethetünk a szervesanyag-mennyiségre. A BOI mértékegysége tehát $\mathrm{O}_{2} \mathrm{~g} \cdot \mathrm{m}^{-3}$, a gyakorlatban $\mathrm{mg} \cdot \mathrm{dm}^{-3}$. A teszt alkalmazható a komposztok érettségének vizsgálatára is, vizes szuszpenziókból (UsUI et al., 1985). A nyers hulladék $\mathrm{BOI}_{5}$ értéke $138 \mathrm{mg} \mathrm{O}_{2} \cdot \mathrm{g}^{-1}$ szerves anyag volt, míg az érett komposzté $6 \mathrm{mg} \mathrm{O}_{2} \cdot \mathrm{g}^{-1}$ sz.a., vagy $25 \mathrm{mg} \mathrm{O}_{2} \cdot \mathrm{g}^{-1}$ szerves anyag. A módszer alkalmazása a sokféle nyersanyag miatt jelent nehézséget. A 20 órás oxigén igény $\left(\mathrm{BOI}_{20}\right)$ egy hónap alatt csökkent (134 $\mathrm{mg} \mathrm{O}_{2} \cdot \mathrm{g}^{-1}$ VS-ról $23 \mathrm{mg} \mathrm{O} \mathrm{O}_{2} \cdot \mathrm{g}^{-1}$ VS-ra), utána már nem változott. $\mathrm{A} \mathrm{BOI}_{20}$ paraméter exponenciálisan csökkent $\left(\mathrm{y}=\mathrm{a} \cdot(1-\mathrm{e})^{\mathrm{bt}}\right.$; az egyenletben az $a=142 \mathrm{mg} \mathrm{O}_{2} \cdot \mathrm{g} \mathrm{VS}^{-1}$ és a $\left.b=0,025 \cdot \mathrm{nap}^{-1} ; \mathrm{R}^{2}=0,96\right)$.

A kémiai oxigén igény (KOI) a folyadékokban vagy szuszpenzióban lévő oxidálható szerves anyagok mennyiségéröl nyújt kvantitatív adatot. A KOI az $1 \mathrm{dm}^{3}$ térfogatú minta által redukált oxidálószerrel egyenértékű oxigén tömegeként adható meg $\left(\mathrm{mg} \cdot \mathrm{dm}^{-3}\right)$. Értékét a komposztstabilitás jellemzőjeként szokták használni, de az eredmények gyakran nem kielégítően pontosak (MATHUR et al., 1993; PAPADIMITRIOU \& BALIS, 1996; LASARIDI \& STENTIFORD, 1997).

A specifikus oxigén felvételi sebesség, SOUR (specific oxygen uptake rate) egy olyan paraméter, amelyet a szuszpenzióban zajló metabolikus folyamatok sebességének meghatározására lehet használni. A SOUR értéke $20 \mathrm{mg} \mathrm{O}_{2} \cdot(\mathrm{g} \mathrm{VS} \cdot \mathrm{h})^{-1}$ értékről $5 \mathrm{mg} \mathrm{O}_{2} \cdot(\mathrm{g} \mathrm{VS} \cdot \mathrm{h})^{-1}$-ra csökkent az aktív komposztálási periódus alatt és $<2,5 \mathrm{mg} \mathrm{O}_{2} \cdot(\mathrm{g} \text { VS } \cdot h)^{-1}$-ra az egyhónapos utóérlelés után, azaz expomenciálisan csökkent $\left(\mathrm{y}=\mathrm{a} \cdot\left(1-\mathrm{e}^{-\mathrm{bt}}\right)\right.$; ahol a $=17,9 \mathrm{mg} \mathrm{O} \mathrm{O}_{2} \cdot \mathrm{g} \mathrm{VS}^{-1}$ és $\mathrm{b}=0,041 \cdot$ nap $\left.^{-1} ; \mathrm{R}^{2}=0,95\right)$ (BARRENA et al., 2005).

A DSOUR (szárazanyagra vetített specifikus oxigénfelvételi sebesség) jól korrelált a SOUR értékkel és a komposztálás idejével. Értéke 2-röl 0,5-re csökkent a hat hónapos kezelés alatt. A SOUR értéke magasabb volt, mint a DSOUR, a közöttük lévő különbség a komposztálás előrehaladtával csökkent. A szennyvíziszapból származó komposzt SOUR értéke alacsonyabb volt, mint $1,5 \mathrm{mg} \mathrm{O}_{2}(\mathrm{~g} \text { VS } \cdot \mathrm{h})^{-1}$, magas stabilizációt mutatott, míg a biostabilizált hulladék a SOUR teszttel kevesebb, mint 2,5 $\mathrm{mg} \mathrm{O}_{2} \cdot(\mathrm{g} \mathrm{VS} \cdot \mathrm{h})^{-1}$ értéke könnyebb kezelhetőséget és tárolást tesz lehetővé (BARRENA et al., 2005).

Németországban és Ausztriában az $\mathrm{AT}_{4}$ értéket (négynapos légzési aktivitás, statikus vizsgálati módszer $-\mathrm{mg} \mathrm{O}_{2} \cdot \mathrm{g} \mathrm{sz.a.}{ }^{-1}$ ) használják fel a komposztok utóérlelésre

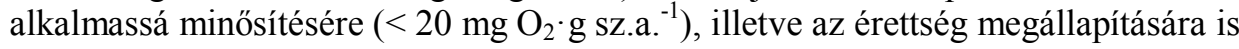


( $<5 \mathrm{mg} \mathrm{O}_{2} \cdot \mathrm{g} \mathrm{sza}^{-1}{ }^{-1}$ (IANNOTTI et al., 1993). Az érett komposzt respirációs aktivitása $\left(\mathrm{AT}_{4}\right)<10 \mathrm{mg} \mathrm{O}_{2} \cdot \mathrm{g} \mathrm{sz.a.}^{-1}$ (CEC, 2001).

A mikrobiális biomasszába tartozó algák és protozoonok általában nagy számban figyelhetők meg az érett komposztban a tárolás során (GLATHE et al., 1985).

Az érés során jelentősen nő a sugárgombák száma, ami BILITEWSKI és munkatársai (1990) szerint a komposztérettség indikátora is lehet. A mikrobiális aktivitás irányítja a szerves anyagok eloszlását a stabil és labilis részek között, különösen a vízoldható fázisban, amely közvetlen hatással van a kész komposzt stabilitására (CHEFETZ et al., 1998; ZMORA-NAHUM et al., 2005; SAID-PULLICINO et al., 2006).

A mikrobiális biomassza közvetlen mérését a komposztérettség indikátoraként lehet figyelembe venni (LYNCH \& WOOD, 1985). A komposztálás termofil szakaszának meghosszabbításával csökkenteni lehet a mikotoxin-termelök túlszaporodásának veszélyét (ÓBERT et al., 2008). A humusztrágyából izolált sugárgomba és mikroszkopikus gomba törzsek antagonista hatása kisebb volt, mint a szennyvíziszap-tartalmú komposztból származó izolátumoké, ezért nitrogénkötő baktériumokkal megfelelően társíthatók (KÖDÖBÖCZ et al., 2005).

Következtetésünk a biológiai módszerekkel végzett vizsgálatok eredményeinek függvényében, hogy a respirációs értékek jól alkalmazhatóak; ezen belül az oxigén felvétel mértéke mutatja leghatékonyabban a komposzt érettségét. A statikus légzési $\mathrm{AT}_{4}$ érték és a dinamikus respirációs index (DRI) jól bevállt vizsgálatok, a SOUR és a DSOUR érték jól korrelál a komposzt korával. A biológiai oxigén igény $\left(\mathrm{BOI}_{5}\right)$ a sokféle nyersanyag miatt okoz nehézséget, a kémiai oxigén igény (KOI) általánosságban nem ad kielégítő eredményt.

\section{A komposztérettség vizsgálatához alkalmazott kémiai módszerek}

A humifikáció folyamata funkciós csoportokat eredményez $(-\mathrm{COOH},-\mathrm{OH}$, $=\mathrm{NH},-\mathrm{NH}_{2}$ ), ez megnöveli a szerves anyagok oxidációját, ami a kationcserekapacitás (CEC; T-érték) megemelkedését eredményezi. Ez utóbbi paraméter tehát felhasználható a komposztok érettségének becslésére.

$\mathrm{Az}$ érettség index javasolt T-értéke: $>60 \mathrm{meq} \cdot 100 \mathrm{~g}^{-1}$. A T-érték azonban változó lehet azonos humusztartalom mellett is, részben abból adódóan, hogy nem minden szerves anyag humusz. Hasonló típusú humuszanyagok eltérő T-értéke részben a kicserélhető helyek blokkolásával, komplexképzéssel (pl. $\mathrm{Cu}, \mathrm{Fe}, \mathrm{Al}$ ionokkal), illetve az amorf Fe és Al-al végbement interakciókkal is magyarázható (MULLER, 1939; HARADA \& INOKO, 1980; LEVI-MINZI et al., 1986)

Az elektromos vezetőképesség (EC), a talaj összes só tartalmának egyszerủ és gyors, fél-kvantitatív meghatározása, amely a telített pép elektromos vezetőképességének mérésén alapszik. Az EC csökkenése kapcsolatban van az oldott tápanyagionok mennyiségének csökkenésével, amelyek az aerob mikroba populációk gyors elszaporodása alatt kötődtek meg és összefügg ezek oldhatatlan ásványi sók formájában történő kicsapódásával, iletve az ammónia elillanásával is. Értékét érettségi indexként figyelembe lehet venni (RAVIV et al., 1987; WONG et al., 2001). 
LASARIDI és munkatársai (1996) szerint az EC növények számára tolerálható maximum értéke $4 \mathrm{dS} \cdot \mathrm{m}^{-1}$ lehet. A kerti komposzt felhasználásával készített termesztő-közegek elektromos vezetöképessége 1,3 és $1,8 \mathrm{dS} \cdot \mathrm{m}^{-1}$ közötti, a szarvasmarhatrágyát is tartalmazó keverék esetén ez az érték tartomány $1,4-1,6 \mathrm{dS} \cdot \mathrm{m}^{-1}$ (PRASAD \& MAHER, 2001).

A CEC/TOC arányt szintén az érettség indikátoraként használják. RoIG és munkatársai (1988), illetve JíMENEZ és GÁRCíA (1992) az 1,7-es értéket javasoltak trágyákhoz és az 1,9-es értéket kommunális szilárd hulladék (KSZH), illetve KSZH és szennyvíziszap tartalmú komposztokhoz. Vizsgálataik során 1,83, 2,45 és 2,28 volt azoknak a komposztoknak a CEC/TOC értéke, melyek KSZH-t tartalmaztak és 3,$50 ; 2,09 ; 2,37$ volt azoké, amelyekben nem volt KSZH. A CEC/TOC arány föként a biooxidatív fázisban növekszik, bár az érési fázisban is lehetett kimutatni emelkedést. Ez a jellegzetesség alkalmassá teszi e mutatót szinte minden típusú komposzt érettségi fokának a meghatározásához.

A szervetlen nitrogénformák közötti arány is használható a komposztérettség meghatározására. A nitrát mennyisége és aránya a nitrifikáció eredményeként növekszik a komposztálás során, így az $\mathrm{NH}_{4} / \mathrm{NO}_{3}$ arány $<1$ lesz a folyamat végére. Ez alapján megállapítható, hogy a komposzt elérte az érettséget (APARNA et al., 2008). A $\mathrm{NH}_{4} / \mathrm{NO}_{3}$ arány megbízhatóan használható a komposztérettség jellemzésére EGAWA (1975), illetve KATAYAMA és munkatársai (1987) szerint is.

SPOHN (1978) egy gyorsteszt során a redoxpotenciált határozza meg, ami alapján következtetni lehet a komposzt érettségére. A komposzt nitrát-N tartalmának értéke nagyon jelentős, ami szintén az érettség egyik jele lehet. BERNAL és munkatársai (1998) egy érettségi indexet határoztak meg (nitrát-N: 0,16\%), ami nagyon eltérő eredetủ komposztoknál is használható. ZUCCONI \& DE BERTOLDI (1987) $0,04 \%$ érettségi limitet határozott meg. Amikor az ammónium-N csökken és a nitrát-N emelkedik, akkor érettnek tekinthető a komposzt (FINSTEIN \& MILLER, 1985). A nagy mennyiségü $\mathrm{NH}_{4}-\mathrm{N}$ instabil anyagra utal.

A kromatográfia a mozgó/mobil fázisban (eluensben) oldott keveréknek egy álló/statikus fázison való áthajtása, mely során a vizsgálandó anyag elválik az elegyben található további molekuláktól. A módszer alkalmas lehetne a különböző érettségü komposztok közötti különbség kimutatására, azok humusz anyag összetételének elemzése alapján, de a humuszanyagok mobilitása eltérő lehet a komposztban lévő komplexképző fémionok eltérő mennyisége miatt. A fémekkel vagy agyagásványokkal alkotott humuszkomplexek csökkentik a humuszanyagok oldhatóságát, így ez az eljárás nem alkalmazható a komposztok érettségének meghatározására (SCHNITZER \& KHAN, 1972; STEVENSON, 1982).

A C/N arány változása tükrözi a szerves anyag dekompozícióját és stabilizálódását - mivel progresszíven csökken a komposztálás alatt - és az érettség hasznos indikátora is lehet (IANOTTI et al., 1994; HUE \& LIU 1995; HADAS \& PORTNOY, 1994; 1997; HUANG et al., 2006).

A vízoldható szerves $C /$ vízoldható szerves $N$ arány $\left(C_{W} / N_{\text {org }}\right) 5-6$ körüli értéke szintén a komposzt érettségét jelzi (HIRAI et al., 1985; ChANYASAK \& KUBOTA, 1981). JIMÉNEZ és GÁRCIA (1992) szerint amennyiben a C/N arány kisebb, mint 12, a komposzt érettnek minősíthetö. 
HUE \& LiU, (1995); BERNAL et al.,(1998) szerint a $\mathrm{C}_{\mathrm{W}} / \mathrm{N}_{\mathrm{org}}$ arány miden esetben csökkent a komposztálás alatt $(0,89-3,52)$ tartományból $(0,32-0,66)$ értékek közé. Érettségi indexként HUE és LIU (1995) a $0,55 \mathrm{C}_{\mathrm{w}} / \mathrm{N}_{\mathrm{org}}$ értéket javasolta határértéknek az érett, stabil komposztok leírásához.

$\mathrm{Az}$ éretlen komposztnak relatív magas a $\mathrm{C}_{\mathrm{org}} / \mathrm{N}_{\text {org }}$ aránya. A C/N arány azonban önmagában nem használható fel az érettség megállapítására egyetlen fajta komposzt esetében sem. Az érettség a következő faktorral (f) jellemezhető (SENESI, 1989):

$$
f=(C / N \text { arány az érés végén }) /(C / N \text { arány az érés kezdetén })
$$

A kezdeti 30 feletti $\mathrm{C} / \mathrm{N}$ arány az érés végére 20 alá csökken (JIMENEZ \& GARCIA, 1989). A $C_{w} / N_{\text {org }}$ arány közvetlenül, nagy valószínüséggel korrelált minden mineralizációs paraméterrel, megerősítve, hogy ez az index használható sokféle komposzt stabilizációjának és érettségének leírására (GRIGATTI, et al., 2003). $\mathrm{Az}$ érett vagy stabil komposztok $\mathrm{C} / \mathrm{N}$ arányára több határértékre vonatkozó javaslat is található a szakirodalomban; 20 (JIMENEZ \& GARCIA, 1989; BERNAL, 1988), 5-6 (CHANYASAK et al., 1982; HIRAI et al., 1985), illetve 0,70 (HuE \& Liu, 1995).

A TOC/TN arány alacsonyabb értéke a szerves anyag stabilizációjának magasabb fokát jelzi. A különböző komposztok kémiai jellemzőit vizsgálva a következö érettségi indexeket lehet megalkotni: $\mathrm{C} / \mathrm{N}<12 ; \mathrm{CW}<1,7 \% ; \mathrm{C}_{\mathrm{W}} / \mathrm{N}_{\text {org }}<0,55$; $\mathrm{NH}_{4} / \mathrm{NO}_{3}<0,16 ; \mathrm{NH}_{4}-\mathrm{N}<0,04 \%$ (BERNAL et al., 1998).

A C/N arány a szilárd fázisban nem használható a komposztérettség abszolút indikátoraként a kiindulási nyersanyagok nagy változatossága miatt. CHARPENTIER és VASSOUT (1985) szerint a szervesanyag-tartalom 50\%-kal, 60\%-ról 30\%-ra csökken a három hónapos komposztálás során. WONG (1985) az előbbiekhez hasonlóan azt tapasztalta, hogy 16 hetes érés során a $\mathrm{C}_{\text {org }}$ 40\%-ról 30\%-ra csökkent. A szervesanyag-tartalom csökkenése a termofil fázisban a legintenzívebb (TÖRÖK, 1959). Az összes kivonható $C_{\text {org }}$ tartalom csökken az érés elörehaladtával, annál eröteljesebben, minél magasabb a kivonható $\mathrm{C}_{\text {org }}$ tartalom (HUE \& LIU, 1995; BERNAL et al., 1998; ChEFEETZ et al., 1998).

A komposztálási folyamat során a kiindulási anyagoktól az érett komposztig (17. nap) tekintélyes csökkenés mutatható ki a paraffin-C tartalomban, a fehérjék és az $\mathrm{OCH}_{3}$ csoportok C-tartalmában, de csak kis csökkenés (65-105 ppm) mutatkozott a szénhidrátok C-tartalmában. A komposztálás alatt növekedett az aromás és a fenolos (lignin) C-tartalom, a $\mathrm{CO}_{2} \mathrm{H}$ csoportok C-tartalma és az aromásság (MARCHEA et al., 2003).

A TOC, a kivonható összes szén (TEC), és a nem humuszosodott C-tartalom csökken a komposztálás során - a szerves anyagok mikroorganizmusok általi mineralizációjának köszönhetően. CIAVATTA és munkatársai $(1990,1993)$ eredményei alapján a TOC és a TEC túlnyomórészt a komposztálás első fázisában csökkent le, köszönhetően az intenzív mineralizációnak.

A vízoldható $\mathrm{C}$ - ami nagy arányban magában foglalja a könnyen biodegradálható szerves összetevőket, mint pl. a cukrok, aminosavak, és fehérjék koncentrációja csökken a komposztálás során (SELlAMI et al., 2008). 
A vízoldható humusz jelenléte a tökéletlen lebomlást jelzi (MATHUR \& FARNHAM, 1985).

A komposztok minőségi osztályozásakor a humifikáció mértéke, a komposztok humuszanyag-tartalma és annak frakciói fontos paraméterek (SCHIEDT, 1989; RIESS \& KLAGES-HABERKERN, 1993). A huminsav-tartalom a komposzt nyersanyagok függvényében változó lehet. A komposzt érése során a kivonható huminsav (HA) mennyisége nö, míg a fulvosavé (FA) csökken (SUGAHARA \& INOKO 1981; HAN et al., 2008), így a humifikációs fok elfogadható érettségi kritériumként (HARADA \& INOKO, 1980; JOURAIPHY et al., 2005). LEVI-MINZI és munkatársai (1986) szerint a HA és FA tartalom alapján egy érettségi indexből is meghatározható az érettség. A humusz kivonhatósága ugyanakkor annak kora vagy érettsége alapján változik, befolyásolhatja továbbá az agyagásványok és a fémek jelenléte - amelyekkel oldhatatlan formákat képezhet. A kivonható humusz mennyisége ezáltal nem minden komposzt esetén jó indikátora a komposztérettségnek (SCHNITZER \& KHAN, 1972; STEVENSON, 1982; MOREL et al., 1985). A teljes szénmennyiség százalékában kifejezett kivonható humusz szén mennyiségét extrakciós aránynak hívják (ESTRADA et al., 1987), értéke a nyersanyag érettségétől függ.

$\mathrm{A} \mathrm{C}_{\mathrm{HA}} / \mathrm{C}_{\mathrm{FA}}$ és a CEC/TOC indexek tünnek a legérzékenyebbnek, amivel a humifikáció folyamatát nyomon lehet követni. Mindkettő index növekszik a komposztálás alatt és korábban is ajánlották az érettség indikátoraként. (RoIG et al., 1988; JIMENEZ \& GARCíA, 1992). A 35. és a 45. nap között a FA/HA arány 4:1, egyéves komposztnál ez az arány 1:1-re csökken (SACHSE \& ZIECHMANN, 1969). Általában a friss és a nyers komposzt kevés HA-t és sok FA-t tartalmaz ellentétben az érett komposzttal (HAN et al., 2008). EsTRADA és munkatársai (1987) kísérleti eredményei alapján a humuszszerü frakciók $\left(\mathrm{C}_{\mathrm{HA}}\right.$ és a humifikációs index $(\mathrm{HI})$ növekszenek a komposztálás alatt, mutatva a humifikáció irányát. A humusz HA + FA frakciói a teljes szerves szénmennyiség arányában növekednek a komposzt érettségével, a $\mathrm{C}$, a $\mathrm{HA} / \mathrm{C}_{\mathrm{FA}}$ arányban növekszik, és megbízhatóan alkalmazható érettségi indexként mindenfajta hulladék esetén. $\mathrm{C}_{\mathrm{HA}} / \mathrm{C}_{\mathrm{FA}}$ arány növekedése a polimerizáció fokaként ismert, a $\mathrm{C}_{\mathrm{HA}}$ jelzi a komplex molekulák kialakulását és a $\mathrm{C}_{\mathrm{FA}}$ és az FA frakció a nem humusz komponensek csökkenését. A polimerizáció foka az érés során $0,65-$ röl 1,86 és 2,00 közé emelkedett, az érett anyagban 0,74 és 3,07 között változott. Ezek jól jelzik a polimerizáció mértékét - és ezáltal a komposzt érettségét is, illetve e jellemző értékek nagyon közel állnak a JíMENEZ \& GARCíA (1992) által javasolt 1,9 érettségi indexhez. A $\mathrm{C}_{\mathrm{FA}}$ értéke azonban széles tartományban mozgott 1,2$3,85 \%$, ami nem tette lehetővé a komposztérettség index létrehozását. $\mathrm{A}_{\mathrm{FA}} / \mathrm{C}_{\mathrm{HA}}$ arány túl nagy eltéréseket mutathat a nyersanyagok függvényében (ESTRADA et al., 1987).

A komposzt érettségének jellemzésére RoLETTO és munkatársai (1985) a következő paraméterek számítását javasolták:

- Humifikációs ráta (HR) amely a teljes kivonható huminsav széntartalmának $\left(\mathrm{C}_{\text {ext }}\right)$ és a teljes szerves széntartalomnak $\left(\mathrm{C}_{\mathrm{org}}\right)$ a százalékban kifejezett aránya: $\mathrm{HR}=\left(\mathrm{C}_{\mathrm{ext}}\right) \cdot\left(100 \cdot \mathrm{C}_{\mathrm{org}}{ }^{-1}\right)$

- Humifikációs index $(\mathrm{HI})$, amely az izolált huminsav széntartalmának $\left(\mathrm{C}_{\mathrm{HA}}\right)$ és a szerves széntartalomnak $\left(\mathrm{C}_{\mathrm{org}}\right)$ a százalékban kifejezett aránya (a nem 
humifikálódott szén és a humusz széntartalmának aránya az $\mathrm{NaOH}+\mathrm{Na}_{4} \mathrm{P}_{2} \mathrm{O}_{7}$ kivonatban $): \mathrm{HI}=\left(\mathrm{C}_{\mathrm{HA}}\right) \cdot\left(100 \cdot \mathrm{C}_{\mathrm{org}}{ }^{-1}\right)$

- Humifikációs fok: az egyes humuszkomponensek stuktúrális (lignin, fenol) változásának szintje.

A komposztérettség meghatározására általánosan alkalmazott paraméterek a DH, a HR, és a HI (Dell'ABate et al., 1998; Dell'ABATE et al., 2000; Dell'ABATE \& TitTARELli, 2002; Mondini et al., 2003). SAVIOZZI és munkatársai (1988) vizsgálataik során azt tapasztalták, hogy a HI a komposzt érettségével csökken. A különbség nem volt elég éles, a nyersanyag HI-e alacsonyabb volt, mint 0,5 és az érett komposzt esetén magasabb, mint 0,4. DeLL'ABATE és munkatársai (1998), Hsu és Lo (1999) TitTARELLI és munkatársai (2002), illetve MONDINI és munkatársai (2003) vizsgálata szerint a HI, a DH és a HR különösen alkalmasak a komposztstabilitás leírására. Nem mutatható ki azonban szignifikáns korreláció a DRI és a humifikációs paraméterek (HI, DH és HR) között. A humifikációs indexek valószínủleg jobban tükrözik a komposzt eredetét, mint a könnyen bontható szervesanyag-tartalmat. Enzimes hidrolízis hatására a DH, HR, HI reálisabb trendet mutatott, és szignifikáns kapcsolatot lehetett kimutatni a WSOC-vel, ami lehetővé teszi a komposztálás érési folyamatának könnyebb és gyorsabb nyomonkövetését, elkerülve a hosszú és drága analitikai eljárásokat.

A humifikáció elörehaladásának és a növekvő kondenzációs fok (illetve molekulatömeg) közti fordított arányosság jellemzésére az egyszerủ fizikai-kémiai módszerek közül elterjedt az $\mathrm{E}_{4} / \mathrm{E}_{6}$ arány (465 nm-en és $665 \mathrm{~nm}$-en mért abszorbancia) meghatározása. $\mathrm{Az} \mathrm{E}_{4} / \mathrm{E}_{6}$ arányt régóta a humusz aromás magjainak kondenzációs foka vagy a humuszérettséget jellemző mutatóként veszik figyelembe (APARNA et al., 2008). A komposztálás elörehaladtával az $\mathrm{E}_{4} / \mathrm{E}_{6}$ arány szignifikánsan csökken. Feltételezhető, hogy a szénhidrátok és a kinonok oxidálódtak és összekapcsolódtak a metoxil csoportokkal és/vagy alifás láncokkal a humusz anyagokban. A komposztálás végén az érettség és stabilitás megfelelő foka alacsonyabb $\mathrm{E}_{4} / \mathrm{E}_{6}$ arány mellett érhető el (SELLAMI et al., 2008).

A komposzt vizes kivonatának optikai sürüség mérése fix hullámhosszon - mint pl. glükométerrel - olcsó és könnyen használható módszer egy átlagos komposztáló telepen is, a komposztérettség meghatározására (MATHUR et al., 1993).

SAID-PULLICINO és munkatársai (2007) vízoldható szervesanyag-minták UV abszorbanciáját mérték $254 \mathrm{~nm}$-en a komposztálás során. A mért abszorbanciát normalizálták a kioldódott szerves szén koncentrációjával, így egy speciális UV abszorpciót kapva (SUVA 254 ), ami a szervesanyag aromás jellegének indikátoraként használható. A vízoldható szerves anyagból nyert $\mathrm{SUVA}_{254}$ értékek állandóak voltak a komposztálás első 28 napjában $0,971 \cdot(\mathrm{mg} \cdot \mathrm{m})^{-1}$ átlagos értékkel, de a mutató értéke később folyamatosan növekedett 1,77 , illetve $3,021 \cdot(\mathrm{mg} \cdot \mathrm{m})^{-1}$ értékig a 90 . és a 250. napra. A szerves oldat UV abszorpciója közvetlenül arányos volt annak aromás összetételével, így az eredmények tisztán mutatták az aromás összetevők relatív növekedését a komposztálás előrehaladtával.

A szénhidrátok, így pl. a monoszacharid koncentráció csökkent a komposztálás során, mind a frakcionálatlan komposztban, mind a HA frakcióban (HäNNINEN et al., 1995). KoIVULA és HäNNINEN (2001) tapasztalatai alapján a D-glükóz mennyi- 
sége csökkent, ugyanakkor a D-xilóz, D-mannóz és D-galaktóz mennyisége a biohulladék komposzt HA frakciójában növekedett a humifikáció alatt. A xilóz és a mannóz mennyisége nőtt a komposztálás 23 hete után. A monoszacharid koncentrációk között az 1-23 hetes komposztok és a fakéreg, valamint az 1, 23 és 36 hetes komposztok között volt szignifikáns különbség. A HA és FA frakciók monoszacharid koncentrációja közötti különbség tanulmányozására a jel tesztet használták, amely alapján koncentrációja szignifikánsan magasabb volt az FA frakcióban, mint a HA-ban $(\mathrm{p}=0,041)$. A monoszacharidok koncentrációja a komposzt huminsavában $52-101 \mathrm{mg} \cdot \mathrm{g}$ szervesanyag ${ }^{-1}$ volt. $^{2}$

A poliszacharid-tartalmat nem lenne praktikus dolog a komposztérettség meghatározására használni. Nem bomlik az összes poliszacharid egyforma gyorsasággal, sőt számos mikroorganizmus poliszacharidokat szintetizál a komposzt érési fázisában. A szénhidrátok átalakulásának nyomonkövetése a komposztálás alatt információkat ad a mikrobiológiai metabolizmus változásáról a komposztálás idejének függvényében, de nem lehet azonosítani általa azokat a biokémiai folyamatokat, amelyek a komposzt stabilitásához és érettségéhez vezetnek (MOREL et al., 1985).

A komposztálás során a szerves anyagok biokémiai átalakulása történik, a metabolizmus oldott szervesanyagban, vízoldható fázisban megy végbe. Ez hasznos a komposztérettség becsléséhez. A komposztok vizes kivonatában a komposztálás kezdeti szakaszában aminosavakat, alifás savakat, peptideket, cukrokat és ezek polimereit lehetett kimutatni (HIRAI et al., 1983). A folyamat elörehaladtával csökken a könnyen metabolizálható és C-ben gazdag alifás és aminosavak mennyisége, míg a N-ben gazdag peptidek növekednek. Egy komposztérettségi szenzor rendszert fejlesztettek ki három, a komposzt minták vizes oldatában elektromosan mérhetö paraméter kombinációját alapul véve: ezek a $\mathrm{pH}, \mathrm{NH}_{4}$ koncentráció és a foszfát aktivitás.

CHANYASAK és KuBOta (1981), GARCía és munkatársai (1992), SAVIOZZI és munkatársai (1987), illetve ZUCCONI és munkatársai (1985) a vízoldható frakció vizsgálata alapján a következő paramétereket javasolták a komposzt érettségi fokának meghatározására: vízoldható szerves szén $\left(\mathrm{C}_{\mathrm{OW}}\right)$, a vízoldható szén és a vízoldható szerves nitrogén aránya $\left(\mathrm{C}_{\mathrm{OW}} / \mathrm{N}_{\mathrm{OW}}\right)$, illetve a vízoldható szerves szén és az összes szerves nitrogén aránya $\left(\mathrm{C}_{\mathrm{OW}} / \mathrm{N}_{\mathrm{ot}}\right)$. $\mathrm{A} \mathrm{C}_{\mathrm{ow}}$ gyorsan csökken a folyamat során, úgy mint a $\mathrm{C}_{\mathrm{OW}} / \mathrm{N}_{\mathrm{OW}}$ és a $\mathrm{C}_{\mathrm{OW}} / \mathrm{N}_{\mathrm{ot}}$ arányok, a fitotoxikus összetevők mennyisége, az ammónia, a kis molekulatömegü szerves savak, fenolok, stb. A csírázási index (Lepidium sativum) nő. A komposztérettség megállapítására javasolt határértékek SANCHEZ-MONDERO és munkatársai (2001), illetve BERNAL és munkatársai (1998) szerint az alábbiak: $\mathrm{C}_{\mathrm{OW}}<0,5-1,7 \%, \mathrm{C}_{\mathrm{OW}} / \mathrm{N}_{\mathrm{OW}} 5-6, \mathrm{C}_{\mathrm{OW}} / \mathrm{N}_{\mathrm{OT}}<0,4(0,55), \mathrm{GI}>60$. A WSC értékek széles skálája javasolt, mert értéke nagymértékben függ a komposzt nyersanyagától (SAVIOZZI et al., 1992; GUERAA-RODRIGUEZ et al., 2001; CHANG et al., 2006; BENITO et al., 2009). A hideg és a forróvíz oldható szerves anyag (OM) összetételét vizsgálva a $\mathrm{C}$ és a $\mathrm{N}$ koncentrációja mindig alacsonyabb volt a hidegvizes (CWE), mint a forróvizes (HWE) kivonatban (hidegvizes kivonat: 2,69$3,95 \mathrm{~g} \mathrm{C} \mathrm{kg}^{-1} ; 0,14-0,29 \mathrm{~g} \mathrm{~N} \cdot \mathrm{kg}^{-1}$; forróvizes kivonat: $13,77-15,51 \mathrm{~g} \mathrm{C}^{-\mathrm{kg}^{-1}} ; 0,34$ $0,83 \mathrm{~g} \mathrm{~N} \cdot \mathrm{kg}^{-1}$ ) (LANDGRAF et al., 2006). A C/N arány HWE esetén szélesebb volt, 
mint CWE esetén. A HWE széntartalom 14 és $27 \mathrm{~g} \cdot \mathrm{kg}^{-1}$ között változott (LANDGRAF et al., 2005).

HARADA és munkatársai (1981) tapasztalatai alapján a HWE OM változása a komposztálás során nem mutat egyértelmü tendenciát - a kivont komponensek értéke majdnem változatlan maradt öt hét után.

A CWE OM thermogramja a szerves anyag volatilizációjának nagy arányát jelezte $400{ }^{\circ} \mathrm{C}$-on. CWE OM termálisan stabilabb volt, mint a HWE OM. A szénhidrátok, a fenolok és a lignin monomerek tömegspektrumában a HWE kivonással kapott értékek intenzívebbek, mint a CWE értékei. Az abszolút és a relatív intenzitás jelezte, hogy több szénhidrát, fenol és lignin monomer oldható a minták forralásával. Söt a HWE OM több heterociklikus N-tartalmú komponenst és peptidet tartalmaz, mint a CWE (LANDGRAF et al., 2005).

A forróvíz oldható teljes $\mathrm{N}$ - és a lignintartalom növekszik a komposztálás során (HARADA et al., 1981).

A CWE módszer esetén erősebb a mikrobiális folyamatok hatása, a hosszú idejü inkubáció miatt, ezért a CWE hasonlóvá válik a HWE-hez. Szignifikáns mikrobióta közremüködés mutatható ki a CWE szervesanyagában (KALBITZ et al., 2003). GREGORICH és munkatársai (2003) nagyobb biodegradálhatóságot mutatott ki a HWE módszerrel előállított mintába, mint a CWE-ben. A HWE-C korrelált a mikrobiális biomassza C-tartalmával, mert a forróvíz kioldja a mikrobiális bomlástermékeket és a dekompozíciós termékeket is. A CWE és a HWE közötti tömegarányban jelentős a különbség (SPARLING et al., 1998; GHANI et al., 2003).

A különböző kivonószerek minél több tápanyagot vonnak ki a talajból, annál erősebben módosítják kémiailag, kolloid-kémiailag annak állapotát. A tápanyagutánpótlással foglalkozó szakemberek régóta szükségesnek látták egy új, rutinszerüen használható a talaj hozzáférhető tápelem-tartalmának a meghatározására alkalmas eljárás megalkotását a víz segítségével. A vizes kivonást, mint módszert, a múlt század közepe óta alkalmazzák. Az első ilyen módszerekkel azonban az elemek analízise nehézkes volt a talajok alacsony vízoldhatósága és a kivont oldat kis elemkoncentrációja miatt (AMER et al., 1955; FrIED \& SHAPIRO, 1956; PAAUW, 1969; NÉMETH, 1976). Többen próbálkoztak a vizes kivonatok töményítésére magas hömérsékletủ extrakciós módszereket kidolgozni (KÖNIG, 1906; BERGER \& TRUOG, 1944; SPARKS et al., 1980; SUNTHEIM \& MATZEL; 1985; CARSKI \& SPARKS, 1987).

Az utóbbi évtizedekben számos módszert vezettek be, hogy javítsák a kivonás hatékonyságát és gyorsítsák a folyamatot. A forróvizes kivonás (hot water percolation - HWP) egy viszonylag új, gyors talajkivonási eljárás (FÜLEKY \& CZINKOTA, 1993). A kávéföző átszürő elvéből kiindulva fejlesztették ki. FÜLEKY és CZINKOTA (1993) a forróvizes kivonási eljárást 36 talajon próbálták ki. A forróvizes kivonás ideje alatt a deszorbeálható, könnyen oldódó elemeket oldották ki a talajmintákból $102-105{ }^{\circ} \mathrm{C}$-os vízzel, $120-150 \mathrm{kPa}$ nyomáson. Az extrakció átlagos ideje 2,6 perc volt, ami lehetőséget adott a kapott értékek kinetikai elemzésére is. Ezzel a módszerrel majdnem minden tápelem $(\mathrm{C}, \mathrm{N}, \mathrm{P}, \mathrm{K})$ kivonható, és nagyságrendileg mérhető. A folyamat variációs koefficiense (CV\%) átlagosan $11 \%$. Az eredmények szoros korrelációban vannak a hagyományos talajvizsgálati eljárások 
eredményeivel, valamint a napraforgó és az angolperje, mint kísérleti növények növénykísérleti eredményeivel is. A HWP forró vizes talajextrakció alkalmazható a talaj tápanyag-szolgáltató képességének nyomonkövetésére is (ELFOUGHI et al., 2010). A pH, elektromos vezetőképesség és a kationcsere kapacitás eredményei is azt bizonyítják, hogy a perkolációs módszer értékes eszköz lehet a tápanyagellátás szintjének a meghatározásához (MARFA et al., 2002). A HWP módszert sikerrel használták a komposztokban végbemenő anyag-átalakulási folyamatok nyomonkövetésére és a végtermékek analízisére is, továbbá TDK-k, diplomák, doktorik születtek belőle.

Következtetésünk a kémiai módszerekkel végzett vizsgálatok eredményeit áttekintve, hogy a $\mathrm{CEC} / \mathrm{TOC}$ és az $\mathrm{NH}_{4} / \mathrm{NO}_{3}$ arányok nagyon jók az érettség meghatározására. A humifikációs indexek (HI, DH, HR) szintén jól alkalmazhatóak, de a mérési eljárás költségei nagyok. $\mathrm{Az} \mathrm{E}_{4} / \mathrm{E}_{6}$ arány meghatározása gyors és olcsó eljárás. Elönye, hogy az $\mathrm{E}_{4} / \mathrm{E}_{6}$ arány a HWP kivonással nyert minták mérési eredményeiből is számítható. A SUVA 254 meghatározása egy új, gyors módszer, ami megbízható eredményeket ad az érettség tekintetében, hiszen az elektromos vezetőképesség (EC) mérése egyszerủ és olcsó. A kationkicserélő képesség (CEC, T-érték) vizsgálata és a spektroszkópia nem megbízható módszerek, a kromatográfiás eljárások pedig nem megfelelőek az érettség meghatározására. A C/N arány, mint komposztérettségi mutató, csak faktorokkal használható, önmagában nem. A szerves-anyag-tartalomból kiinduló meghatározási módszer azért nem megbízható, mert a minták szervesanyag-tartalmának könnyen oldható hányada a humusztartalom és a nyersanyag függvényében változó mértékü, az oldhatatlan formák kialakulása befolyásolja a mérést, a szénhidráttartalom komponensei nem bomlanak egyformán, sőt bizonyos mikroorganizmusok szintetizálnak is poli-szacharidokat.

\section{Következtetések}

Hazánkban jelenleg a komposztok forgalomba hozatalát a 36/2006 (V. 18.) FVM rendelet szabályozza, amiben a kötelező vizsgálatok közül csak négyből lehet közvetlenül vagy közvetve a komposzt érettségére, illetve stabilitására következtetni, ezek a szín, a szag, a kémhatás és az összes sótartalom meghatározás módszerei. A többi vizsgálat a tápanyagtartalmat, a szerves és szervetlen szennyezőanyagtartalmat, illetve a komposzt higiénés állapotát mutatja meg. A nyugati országokban alkalmazzák az önhevülési (Dewar) tesztet az érettségi fok megállapítására, de a komposztokra vonatkozóan egyéb, egységes eljárás nem terjedt el a gyakorlatban. A mechanikai biológiai hulladékkezelés $(\mathrm{MBH})$ során az $\mathrm{AT}_{4}, \mathrm{TOC}, \mathrm{DOC}$ értékek vizsgálati eredményeit használják az érettség és a lerakhatóság megállapításához.

A komposzt érettsége/stabilitása számos vizsgálati módszerrel megállapítható, eltérő pontossággal és biztonsággal. Ezeket a módszereket fizikai, biológiai és kémiai vizsgálatokra lehet csoportosítani. A komposzt elöállítók számára egyszerü, gyors, olcsó eljárásként javasolható a stabilitás és/vagy érettség megállapításához, például a Dewar teszt, vagy a kémhatás, illetve a vezetőképesség (sótartalom) mérése, vagy valamelyik légzési paraméter meghatározása gyors-teszttekkel. 
A laboratóriumi berendezéseket igénylő légzésintenzitást mérő eljárások kizárólag kísérleti céllal javasolhatóak a kutatómühelyek számára, elsősorban a gyakorlat számára ajánlott vizsgálatok módszertani finomítása, pontosítása és a vizsgált jellemzők közötti összefüggések feltárására, illetve a mérési eredmények jobb értékelhetősége érdekében.

Komposztálási technológia alapján nem lehet és nem is szabad eljárást ajánlani a stabilitás szintjének és az érettség fokának megállapítására, hiszen a folyamat ugyan azonos lépésekben - sok esetben eltéró sebességgel játszódik le. A komposztálás nyersanyagösszetétele továbbá hatással van egyes komponensek mennyiségének és arányának változására, így az összetevők meghatározása alapján kis biztonsággal lehet az érettségre következtetni.

\section{Irodalom}

Adani, F., Gonfalonieri, R. \& Tambone F., 2004. Dynamic respiration index as descriptor of the biological stability of organic wastes. Journal of Environmental Quality. 33. 1866-1876.

ADANI, F., UBBIALI, C. \& GENERINI, P., 2006. The determination of biological stability of composts using the Dynamic Respiration Index: The results of experience after two years. Waste Manage. 26. 41-48.

Alburquerque, J. A. GonzÁlvez, J. García, D. \& Cegarra, J., 2004. Agrochemical characterisation of "alperujo", a solid by-product of the two-phase centrifugation method for olive oil extraction. Bioresource Technology. 91. 195-200.

Alburquerque, J. A., Gonzálvez, J., Garcia, D. \& Ceggarra, J., 2005. Composting of a solid olive-mill by-product (alperujo) \& the potentiel of the resulting compost for cultivating pepper under commercial conditions. Waste Management. 26. 620626.

Amer, F., Bouldin, D. R., Black, C. A. \& DuKe, F. R., 1955. Characterization of soil phosphorus by anion exchange resin adsorption and P32-equilibration. Plant and Soil. 6. 391-408.

Aparna, C., Saritha, P., Himabindu, V. \& Anjaneyulu, Y., 2008. Techniques for the evaluation of maturity for composts. Waste Management. 28. 1773-1784.

Barrena Gómez, R., VÁzquez lima, F., Gordillo Bolasell, M. A., Gea, T., BenDOR, E., INBAR, Y. \& CHEN, Y., 1997. The reflectance spectra of organic matter in the visible near-infrared \& short wave infrared region (400-2 $500 \mathrm{~nm}$ ) during a controlled decomposition process. Remote Sensing of Environment. 61.1-15.

Benito M., Masaguer A., Moliner A., Hontoria C. \& Almorox J., 2009. Dynamics of puring waste and spent horse litter co-composting as determined by chemical parameters. Bioresource Technology. 100. (1) 497-500.

Berger, K. C. \& Truog, E., 1944. Boron tests and determination for soils and plants. Soil Science. 57. 25-36.

Bernal, M. P., NAVARro, A. F., SÁnchez-Monedero, M. A., Roig, A. \& Cegarra, J., 1998. Influence of sewage sludge compost stability and maturity on carbon and nitrogen mineralization in soil. Soil Biology and Biochemistry. 30. (3) 305-313. 
Bilitewski, B., HäRdtle, G. \& MAREK, K., 1990. Abfallwirtschaft. Springer Verlag. Stuttgart.

Blanco, M. J. \& Alemendros, G., 1994 Maturity Assessment of wheat straw compost by thermogravimetric analysis. Journal of Agricultural and Food Chemistry. 42. 2454-2459.

Brewer, L. J. \& Sullivan, D. M., 2001. A quick look at quick compost stability test. Biocycle. 42. 53-55.

BREWER, L. J. \& Sullivan, D. M., 2003. Maturity and stability evaluation of composted yard trimmings. Compost Science and Utility. 11. 96-112.

Butler, T. A., Sikora, L. J., Steinhilber, P. M. \& Douglass, L. W., 2001. Compost age and sample storage effects on maturity indicators of biosolids compost. Journal of Environmental Quality. 30. 2141-2148.

CARSKI, T. H. \& SPARKS, D. L., 1987. Differentiation of Soil Nitrogen Fractions Using a Kinetic Approach. Soil Science Society of America. 51. 314-317.

Castaldia P., Albertib, G., MerellaA, R. \& Melisa, P., 2004. Study of the organic matter evolution during municipal solid waste composting aimed at identifying suitable parameters for the evaluation of compost maturity. Waste Management. 25. 209-213.

CCQC (CAlifornia Compost Quality Council) 2001. Compost Maturity Index. Technical Report.

CEC, 2001. Working document on biological treatment of biowaste 2nd Draft. ENV.A.2./LM

Chang, J. I., Tsai, J. J.\& WU, K. H., 2006. Bioresource Technology. 97. 116.

Chanyasak, V. \& Kubota, H., 1981. Carbon/organic nitrogrn ratio in water extract as measure of compost degradation. Journal of Fermentation Technology. 5. 215219.

ChanyasaK, V., HiRAi, M. \& CUBOTA, H., 1982. Changes of chemical components and nitrogen transformation in water extracts during composting of garbage. Journal of Fermentation Technology. 60. 439-446.

Charpentier, S. \& F. VASSOUT., 1985. Soluble salt concentrations and chemical equilibria in water extracts from town refuse compost during composting period. Acta Horticulturae. 172. 87-93.

Chefetz, B., Adani, F., Genevini, P., Tambone, F., Hadar, Y. \& Chen, Y., 1998a. Humic-acid transformation during composting of municipal solid waste. Journal of Environmental Quality. 27. 794-800.

Chefetz, B., Hadar, Y. \& Chen, Y., 1998b. Dissolved organic carbon fractions formed during composting of municipal solid waste: Properties and significance. Acta Hydrochimica et Hydrobiologica. 26. 172-179.

Chen, I.-C. K., Coffey, J. T. \& Mudge, T. N., 1996. Analysis of Branch Prediction Via Data Compression. In ASPLOS VII. 128-137.

CHEN, Y. N., 2003. Nuclear magnetic resonance, infra-red amd pyrolysis: Application of spectroscopic methodologies to maturity determination of composts. Compost Science and Utility. 11. 152-168.

Ciavatta, C., Govia, M., Antisaria, V. L. \& Sequi, P. 1990. An enzymatic approach to the determination of the degree of stabilization of organic carbon fertilizers. Fertilizer Research. 25. 167-174. 
Ciavatta, C., Govia, M., Simoni, A. \& Sequi, P., 1993. Evaluation of heavy matels during stabilization of organic matter in compost produced with municipal solid wastes. Bioresource Technology. 43. 147-153.

Ciavatta, C., Govia, M., Vittori Antisaria, L. \& Sequia, P., 1991. Determination of organic carbon in aqueous extracts of soils and fertilizers. Communications in Soil Science and Plant Analysis. 22. 795-807

Couteaux M. M., BotTner P. \& BerG B., 1995. Litter decomposition, climate and litter quality. Tree. 10. 63-66.

Dell'Abate M. T. \& TitTarelli, F., 2002. Monitoring of a composting process: Thermalstability of raw materials and products. In: Microbiology of Composting. (Eds.: Insam, H., RidDeCH, N. \& KlAMmeR, S.) 357-372. Springer. Heidelberg. Germany.

Dell'Abate, M. T., Benedetti, A. \& Sequi, P., 2000. Thermal methods of organic matter maturation monitoring during a composting process. Journal of Thermal Analysis and Calorimetry. 61. 389-396.

Dell’Abate, M. T, Canali, S., Trinchera, A., Benedetti, A. \& Sequi, P., 1998. Thermal analysis in the evaluation of compost stability: a comparison with humification parameters. Nutrient Cycling in Agroecosystems. 51. 217-224.

Derikx, P. J. L., Op Den CAmp, H. J. M., VAn Der Drift, C., VAn Griensven, L. J. L. D. \& VogEls, G. D., 1990. Biomass and biological activity during the production of compost used as a substrate in mushroom cultivation. Applied Environmental Microbiology. 56. (10) 3029-3034.

De Vleeschauwer, D., Verdonck, O., Van \& Assche P., 1981. Phytotoxicity of Refuse Compost. Biocycle. 22. 44-46.

DuNST, G., 1991. Kompostierung. Leopold Stocker Verlag. Graz-Stuttgart.

EGAWA, T., 1975. Utilization of organic fertilizers in Japan. In Organic Materials as Fertilizers. FAO Soil Bulletin. 27. 253-271.

Elfoughi A., BenedeK Sz., BAyoumi H. A. F. \& Füleky Gy., 2010. Komposzttrágyázás hatásának vizsgálata a talaj tápelem-szolgáltató képességére. Agrokémia és Talajtan. 59. 315-328.

Estrada, J., Sana, J., Cequeil, R.M. \& Cruanas, R., 1987. Application of a new method for CEC determination as a compost maturity index. In: Compost: Production, Quality and Use. (Eds.: De Bertoldi, M., Ferranti, M. P., L’Hermite, P. AND Zucconi, F.) 334-340. Elsevier Applied Science. London. UK.

Finstein, M. S. \& Miller, F. C., 1985. Principles of composting leading to maximization of decomposition rate, odor control, \& cost effectiveness. In: Composting of Agricultural and Other Wastes. (Ed.: GASER, J. K. R.) 13-26. Elsevier Applied Science Publisher. Barking. Essex.

Finstein, M. S., Miller, F. C. \& Strom, P. F., 1986. Monitoring and evaluating composting process performance. J.Water Pollution Control Federation. 58. (4) 272-278.

Fried, M. \& Shapiro, R. E., 1956. Phosphate Supply Pattern of Various Soils. Soil Science Society of America. 4. 471-475.

FÜleKY, Gy. \& CZINKOTA, I., 1993. Hot water percolation (HWP): A new rapid soil extraction method. Plant and Soil. 157. 131-135. 
Garcia, C., Hernández, T., CostA, C \& Ayuso, M., 1992. Evaluation of the maturity of municipal waste compost using simple chemical parameters. Communication in Soil Science and Plant Analysis. 23. 1501-1502.

Ghani, A., DeXter, M. \& Perrott, K. W., 2003. Hot-water-extractable carbon in soils: a sensitive measurement for determining impacts of fertilisation, grazing and cultivation. Soil Biology and Biochemistry. 35. 1231-1243.

Gillon, D., Joffre, R. \& Dardenne, P., 1993. Predicting the stage of decay of decomposing leaves by near infrard reflectance spectroscopy. Canadian Journal of Forest Research. 23. (12) 2552-2559.

Glathe, H., Küster, E., Niese, G. \& A. Von KlopoteK., 1985. Biologie der Rotteprozesse bei der Kompostierung von Siedlungsabfälle. In: Handbuch für Müll- und Abfallbeseitigung. (Ed.: HöSEL, G. SCHENKER, W. \& SCHNURER, H (Hrsg)) 145-170. Erich Schmidt Verlag. Berlin.

Golueke, C. G., 1977. Biological Reclamation of Solid Wastes. Rodale Press. Emmaus, Pa. U. S. A.

Gregorich, E. G., Beare, M. H., Stoklas, U., \& St-Georges, P., 2003. Biodegradability of soluble organic matter in maize-cropped soils. Geoderma. 113. 237-252.

Grigatti, M., Ciavatta, C. \& Gessa, C., 2004. Evolution of organic matter from sewage sludge and garden trimming during composting. Bioresource Technology. 91. 163-169.

Guerra-Rodriguez E., DiAz-RAvina M. \& VÁzQuez M., 2001. Bioresource Technology. 78. 107.

Guisquiani, P. L., Pagliai, M., Gigliotti, G., Businelli, D. \& Benetti, A., 1995. Urban waste compost: Effects on physical, chemical, and biochemical soil properties. Journal of Environmental Quality. 24. 175-182.

HadAs, A. \& Portnoy, R., 1994. Nitrogen and carbon mineralization rates of composted manure incubated in soil. Journal of Environmental Quality. 23. 1184 1189.

Hadas, A. \& Portnoy, R., 1997. Rates of decomposition in soil and release of available nitrogen from cattle manure and municipal waste composts. Compost Science and Utilization. 5. (3) 48-54.

HÄNNINEN I. K., KOVALAINEN J. T. \& KORVOLA, J., 1995. Drum composting of bio sludges and solid biowaste. Compost Science and Utilization. 3. 51-68.

HARADA Y., INOKO A., TADAKI M. \& IZAWA T., 1981. Maturing process of city refuse compost during piling. Soil Science and Plant Nutrition. 27. (3) 357-364.

HARADA, Y. \& INOKO, A., 1980. The measurement of the cation echange capacity of composts for the estimation of the degree of maturity. Siol Science and Plant Nutrition. 25. 127-134.

Hartmann, H. P. \& APPEL, T., 2006. Calibration of near infrared spectra for measuringdecomposing cellulose and green manure in soils. Soil Biology and Biochemistry. 38. 887-897.

Haug, R. T., 1993. The Practical Handbook of Compost Engineering. Lewis Publishers. USA.

Hirai, M. F., Chanyasak, V. \& Kubota, H., 1983. Standard measurement for compost maturity. Biocycle. Nov/Dec. 54-56. 
Hirai, M. F., Chanyasak, V. \& Kubota, H., 1985. Measuring for compost maturity: Using the organic-carbon/organic-nitrogen ratio in water extract. In: Managing Sludge by Composting. (Eds.: THE STAFF OF BIOCYCLE) 221-225. JG Press Inc. Emmaus. USA.

HsU, J. H. \& LO, S. L., 1999. Chemical and spectroscopic analysis of organic matter transformations during composting of pig manure. Environmental Pollution. 104. 189-196.

Huang, G. F., Wu, Q. T., Wong, J. W. C. \& Nagar, B. B., 2006. Transformation of organic matter during co-composting of pig manure with sawdust. Bioresource Technology. 97. 1834-1842.

Hue, N. V. \& LiU, J., 1995. Predicting compost stability. Compost Science and Utilization. 3. 8-15.

iannotti, D. M., Grebus, M. E., Toth, B. L., Madden, L. V. \& Hoitink, H. A. J., 1994. Oxygen respirometry to assess stability and maturity of composted municipal solid waste. Environmental Quality. 23. 1177-1183.

ianotti, D. A., Pang, T., Toth, B. L., Elwell, D. L., Keener, H. M. \& Hoitink, H. A. L., 1993. A quantitative respirometric method for monitoring compost stability. Compost Science and Utilization. 1. 52-65.

ianotti, D. A., Grebus, M. E., Toth, B. L., Madden, L. V. \& Hoitink, H. A. J., 1994. Oxygen respirometry to assess stability and maturity of composted municipal solid waste. Journal of Enwironmental Quality. 23. 1177.

INBAR, Y., CHEN, Y. \& HADAR, Y., 1989. Solid state Carbon-13 nuclear magnetic resonance and infrared spectroscopy of composted organic matter. Soil Science Society of America Journal. 54. 1695-1701.

INBAR, Y., CHEN, Y. \& HADAR, Y., 1990. Humic substances formed during the composting of organic matter. Soil Science Society of America Journal. 54. 13161323 .

InOKO, A. \& FuJIWARA, S., 1979. Possibility of rapid test for check the maturities of animal excrements through the paper chromatographic method. Journal of the Science of Soil and Manure, Japan. 50. 517-522.

INOKO, A., 1979. A rapid test for the check of maturity of city refuse composts using a paper chromatographic method. Journal of the Science of Soil and Manure, Japan. 50. 127-132.

InOKO, A., MiYAmatsu, K., Sugahara, K. \& HaradA, Y., 1979. On some organic constituents of city refuse composts produced is Japan. Soil Science and Plant Nutrition. 25. 225-234.

TuOmela, M., Vikman, A., HATAKKA, M. \& ItAVAara, M., 2000. Biodegradation of lignin in a compost environment: a review Bioresource Technology. 72. 169-183

JimÉnEZ, E. I. \& GARCIA, V. P., 1989. Evaluation of city refuse compost maturity. A Review. Biological Wastes. 27. 115-142.

JimeneZ-IGLESIAS, E. \& GARCIA-PEREZ, V., 1992. Composting of domestic refuse and sewage sludge. II. Evolution of carbon and some „humification”indexes. Resources, Conservation and Recycling. 6. 243-257.

Joffre, R., Gillona, D., Dardenneb, P., Agneessensb, R. \& Bistonb, R., 1992. The use of near-infrared reflectance spectroscopy in litter decomposition studies. Annals of Forest Science. 49. (5) 481-488. 
Jourariphy, S., Amir, M., El Gharous, J., Revel, C. \& HAFIDI, M., 2005. Chemical and spectroscopic analysis of organic matter transformation during composting of sewage sludge and green plant waste. International Biodeterioriation and Biodegradation. 56. 101-108.

JourdAN, B., 1988. Zur Kennzeihnug des Rottesgrases von Müll- und Müll klarschlammkomposten. Erich-Schmid Verlag. Stuttgart.

Kalbitz, K., Schesig, D., Schmerwitz, J., Kaiser, K., Haumaier, L., Glaser, B., Ellerbrock, R. \& LeinweBer, P., 2003. Changes in dissolved organic matter properties induced by biodegradation. Soil Biology and Biochemistry. 35. 11291142.

Katayama, A., Kerr, K.C., Hirai, M., Shoda, M. \& Kubota, H., 1987. Stabilization process of sewage sludge compost in soil. In: Compost: Production , Quality and Use. (Eds.: De Bertoldi, M., Ferranti, M. P., L’Hermite, P. \& Zucconi, F.), 341-350. Elsevier Applied Science. London. UK.

KirChmann, H. \& WidÉN, P., 1994. Separately collected organic household wastes. Swedish Journal of Agricultural Research. 24. 3-12.

Ko, H. J., KIM, H. Y. KIM, H. T., KIM, C. N. \& UMEDA, M., 2008. Evaluation of maturity parameters and heavy metal contents in composts made from animal manure. Waste Management. 2008. 813-820.

Koivula, N. \& HÄNnINEN, K., 2001. Concentrations of monosaccharides in humic substrates in the early stages of humification. Chemosphere. 44. 271-279.

KovÁCs D., RózsÁNÉ SzÜCS B. \& FÜLEKY GY., 2007. Komposztok érettségének meghatározása oxigénfogyasztás, szén-dioxid termelés mérésével és önhevülési teszttel. Agrokémia és Talajtan. 56. 301-316.

KÖDÖBÖCz L., KÁRPÁTI É., DusHA I. \& BIRÓ B., 2005. Asszociatív nitrogénkötő oltóanyagtörzsek túlélőképességét befolyásoló tényezők két potenciális vivőanyagban. Agrokémia és Talajtan. 54. 177-188.

KÖNIG, J., 1906. Die untersuchung landwirtschaftlich und gewerblich wichtiger stoffe: Praktisches handbuch. Berlin. P. Parey.

Körner, I., Braukmeier, J., Herrenklage, J., Leikam, K., RitzKowski, M. Schlegelmilch, M. \& Stegmann, R., 2003. Waste Management. 23. 17.

LAGA, 1984. Qualitatskriterien und Anwendungsempfelhungen für Kompost aus Müll und Müllklarschlamm. (Quality criteria and application recommendations for compost from waste and sludge) Merkblatt 10 der Landerarbeitsgemeinschaft Abfall. Erich Schmidt Verlag. Berlin.

LANDGRAF, D., Leinweber, P. \& MAKenschin, F., 2006. Cold and hot waterextractable organic matter as indicators of litter decomposition in forest soils. Plant Nutrition and Soil Science. 169. 76-82.

LASARIDI, K. \& STENTIFORD, E., 1996. Respirometric techniques in the context of compost stability assessment. Principle and practive. In: The Science of Composting, European Comission International Symposium. (Eds.: DE BERTOLDI, M., SeQui, P., LeMmes, B. \& PAPI, T.) 567-576. Blackie Academic and Professional. Glasgow. Scotland.

LASARIDI, K. \& STENTIFORD, E., 1997. Respirometric techniques and seed bioassays for compost stability evaluation: a comparative study. ORBIT 97 Conference on Organic Recovery and Biological Treatment, 3-5 September 1997. Harrogate. UK. 303-310. 
LASARIDi, K. \& Stentiford, E., 2000. Why and how to test composts for stability. Waste Management. 47-48.

LASARIDi, K., PAPAdimitriU, E. \& BAlis, C., 1996. Development and demonstration of a thermogradient respirometer. Compost Science and Utilization. 4. (3) 53-61.

LEE, R. B., 1977. Effects of organic acids on the loss of ions from barley roots. Journal of experimental Botany. 28. 578-587.

LEVI- MinZI, R., RiffAldi, R. \& SAVIOZZI, A., 1986. Organic matter and nutrients in fresh and mature farmyard manure. Agricultural Wastes. 16. 225-236.

LIMA, F. V. \& FERRER, A. S., 2006. The use of respiration indices in the composting process. A review. Waste Management and Research. 24. 37-47.

LOPEZ REAL \& BAPTISTA, 1996. A preliminary comparative study of three manure composting systems and their influence on process parameters and methane emissions. Compost Science and Utilization. 4. (3) 71-82.

LYNCH, J. M. \& WoOD, D. A., 1985. Controlled microbial degradation of lignocellulose: the basis for existing and novel approaches to composting. In: Composting of Agricultural and Other Wastes. (Ed.: GASSER, J. K. R.) 183-193. Elsevier Applied Science. London.

LYNCH, J. M., 1977. Phytotoxicity of acetic acid produced in the anaerobic decomposition of wheat straw. The Journal of Applied Bacteriology. 42. 81-87.

Malley, B. E., Martin, P. D. \& Ben-Dor, E., 2004. Application in analysis of soils. American Society of Agronomy. Medison. WI. 729-784.

Manios, V. I., Tsikalas, P. E. \& Siminis, H. I., 1989. Phytotoxicity of olive tree compost in relation to organic acid concentration. Biological Wastes. 27. 307-317.

Marchea, T., Schnitzerb, M., Dinelb, H., Pare' B, T., Champagnea, P., SCHULTENC, H. R. \& FACEYD G., 2003. Chemical changes during composting of a paper mill sludge-hardwood sawdust mixture. Geoderma. 116. 345-356.

Marfa, O., Lemaireb, F., Caceresa, R., Giuffridac, F. \& Guerin, V., 2002. Relationships between growing media fetility percolate composition and fertigation strategy in peat substitute substrates used for growing ornamental shrubs. Scientia Horticulturae. 94. 309-321.

MATHUR, S. P. \& FARNHAM, R. S., 1985. Geochemistry of humic substances in natural and cultivated peatlands. In: Humic Substances in Soil, Sediment and Water. (Eds.: Aiken, G. R., McKnight, D. M., WARAShaw, R. L. \& MACCARThY, P.) 5385. John Wiley. NY.

MATHuR, S. P., 1982. The role of soil enzymes in the degradation of organic matter in the tropic, subtropic and temperate zones. Transactions of the $12^{\text {th }}$ Congress of International Soil Science. 1. 125-136.

Mathur, S. P., Owen, G., Dinel, H. \& Schnitzer, M., 1993. Determination of Compost Biomaturity. Literature Review. Biological Agriculture and Horticulture. 10. $65-85$.

MCAdAms, M. W. \& White, R. K., 1996. Compost stability determination. composting in the Carolinas - Proceedings of the 1996 Conference. October 23-25. Clemson University. Myrtle Beach. South Carolina.

McConnell, D.B., Shiralipour, A. \& Smith, W. H., 1993. Compost application improves soil properties. Biocycle. 34. (4) 61-63. 
Mondini, C., Dell'Abate, M.T., LeitA, L. \& Benedetti, A., 2003. An integrated chemical, thermal and microbiological approach to compost stability evaluation. Journal of Environmental Quality. 32. 2379-2386.

Morel, J. L., Colin, F., Gernon, J. C., Godin, P. \& Juste, C., 1985. Methods for evaluation of the maturity of municipal refuse compost. AGRIS. 2013. 56-72.

MUller, J. F., 1939. Some observations on base exchange in organic materials. Soil Science. 25. 229-237.

NANnipieri, P., Greco, S. \& CECCANTI, B., 1990. Ecological significance of the biological activity in soil. In: Soil Biochemistry 6. (Eds.: BollaG, J. M. \& STOZKY, G.) 293-355. Marcel Dekker. New York.

NÉMETH, K. 1976. Die effektive und potentielle Naehrstoffverfuegbarkeit im Boden und ihre Bestimmung mit Elektro-Ultrafiltration (EUF). PhD Thesis. Universität Giessen.

NORDTEST REPORT NT TECHN REPORT 404 (Approved 1998-10) Assessment of Compost Maturity and Ecotoxicity.

Óbert M., Csepregi A., Posta K., Tóth Király E. \& Hornok L., 2008. Szennyvíziszap és zöldhulladék alkotta komposztkeverékből izolált gombák jellemzése. Agrokémia és Talajtan. 57. 319-332.

Oliveira, De S. C., Provenzano, M. R., Santiago Silva, M. R. \& Senesi, N., 2002. Maturity Degree of Composts from Municipal Solid Wastes Evaluated by Differential Scanning Calorimetry, Environmental Technology. 23. 1099.

PAlETSKI, W. T. \& YounG, J. C., 1995. Stability measurement of biosolids compost by aerobic respirometry. Compost Science and Utilization. 3. 16-24.

PApadimitriU, E. K. \& BAlis, C., 1996. Comparative study of parameters to evaluate and monitor the rate of a composting process. Compost Science and Utilization. 4. (4) $52-61$.

PAS 100 Publicly Available Specification - PAS 100 Specification for composted materials.

PrASAD, M. \& MAHER, M. J., 2001. The use of composted green waste as a component of growing medium. Acta Horticulturae. 549. 107-114.

Raviv, M., TARre, S., Geler, Z. \& Shelef, 1987. Changes in some physical and chemical properties of fibrous solids from cow manure and degested cow manure during composting. Biological Wastes. 19. 309-318.

REINIKAINEN, O. \& HERRANEN, M. (2001) Different methods for measuring compost stability and maturity. Acta Horticulturae. 549. 99-104.

RibaldA, R., Moré, J. C. \& SANA, J., 1987. The priming effect and the respiratory rate/compost dose ratio as compost ripeness index. In: Compost: Production, Quality and Use. (Eds.: De Bertoldi, M. Ferranti, M. P., L’Hermite, P. \& ZuCCONI, F.) 328-333. Elsevier Applied Science. London. UK.

Riess, P. \& Klages-HaberkeRn, S., 1993. Qualitätskriterien für Kompost. Entsorgungspraxis Spezial. 9.

Riffaldi , R., Levi-Minzi, R., PerA, A. \& DE Bertoldi, M., 1986. Evaluation of Compost Maturity by Means of Chemical and Microbioal Analyses. Waste Management and Research. 4. 387.

Roig, A., Lax, A., Cefarra, J., Costa, F. \& Hernández, M. T., 1988. Cation exchange capacity as a parameter for measuring the humification degree of manures. Soil Science. 146. 311-316. 
Roletto, E., BArberis, M., Consignlid M. \& Jodice R., 1985. Biocycle. March. 4648.

SACHSE, B. \& ZIECHMANN, W., 1969. Eigenschaften und Verteilungen von Huminstoffen als Kriterien von Rottevorgängen in Müllkomposten. Kali Briefe Fachgebiet. 8. 7.

Said Pullicino, D., Kaiser, K., Guggenberger, G. \& Gigliotti, G., 2007. Changes in the chemical composition of water-extractable organic matter during composting: Distribution between stable and labile organic matter pools. Chemosphere. 66. 2166-2176.

SÁNCHEZ FERRER, A., 2005 Respirometric assays at fixed and process temperatures to monitor composting process. Bioresource Technology. 96. 1153-1159.

Sánchez-Monedero, M. A., Roig, A., Paredes, C. \& Bernal, M. P., 2001. Nitrogen transformation during organic waste composting by the Rutgers system and its effects on $\mathrm{pH}, \mathrm{EC}$ and maturity of the composting mixtures. Bioresource Technology. 78. (3) 301-308.

SAVIOZZI, A., LEVI-MinzI, R. \& RiffaldI, R., 1988. Maturity evaluation of organic waste. Biocycle. 29. (3) 54-56.

SAviozzi, A., LeVi-Minzi, R., Riffaldi, R. \& Benetti A., 1992. Biocycle. 33. 72.

SAVIOZZI, A., RIFFALDI, R. \& LEVI-MinZI, R., 1987. Compost maturity by water extract analysis. In Compost: Production, Quality and Use. (Eds.: DE BerToldi, M. Ferranti, M. P., L’Hermite, P. \& Zucconi, F.) 359-367. Elsevier Applied Science. London. UK.

SCHIEDT, M., 1989. Über die Humusqualität verschiedener Komposte. Mitteln. Dtsch. Bodenkundl. Gesellsch. 59. 465-470.

SCHNitZER, M. \& KAHN, M., 1987. Humic Substances in the Environment. MarcelDekker. NY.

SCHNITZER, M. \& KHAN, S. U., 1972. Humic substances in the environment. Marcell Dekker. NY.

Sellami F., Hachicha S., Chtourou M., Medhioub K. \& Ammar E., 2008. Maturity assessment of composted olive mill eastes using UV spectra and humification parameters. Bioresource Technology. 99. (15) 6900-6907.

SEPA, 1997. Report: Compost Quality and Potential for Use. Swedish EPA. AFR-154, Stockholm. Sweden.

Shiralipour, A., Dennis, B., McConnell, Wayne \& Smith, H., 1992. Physical and chemical properties of soils as affected by municipal solid waste compost application. Biomass and Bioenergy. 3. (3-4) 261-266.

Sparks, D. L., ZelazNy, L. W. \& Martens, D. C. 1980. Kinetics of Potassium Desorption in Soil using Miscible Displacement. Spil Science Society of America. 6. 1205-1208.

Sparling, G. P., Vojvodic-Vukovic, M. \& SchipPer, L. A., 1998. Hot-water soluble C as a simple measure of labile soil organic matter: the relationship with microbial biomass C. Soil Biology and Biochemistry. 30. 1469-1472.

SpoHn, E., 1978. Determination of compost maturity. Compost Science/Land Utilization. May-June. 26-28

STENTIFORD, E., 2002. The Specific Oxygen Uptake Rate (SOUR) - the English practice. In: The Biological Treatment of Biodegradable Waste - Technical aspects. April 8-April10. Brussels. 
http://europa.eu.int/comm/environment/waste/eventspast/bio_programme.htm $(07 / 01 / 05)$.

Stevenson, F. J., 1982. Humus Chemistry: Genesis, Composition, Reactions. John Wiley and Sons. New York. NY.

STICKELBERGER, D., 1975. Survey of city refuse cmposting. In: Organic Materials and Fertilizers. FAO Soils Bulletin. 27. Rome.

SueharA, K., NAKANO, Y. \& YANO, T., 2001. Simultaneous measurement of carbon and nitrogen content of compost using near infrared spectroscopy. 9. (1) 35-41.

SugAHARA, K. \& INOKO, A., 1981. Composition analysis of humus and characterization of humic acid obtained from city refuse compost. Soil Science and Plant Nutrition. 27. 213-224.

Sugahara, K., Harada, Y., \& InOKO, A., 1979. Color change of city refuse during composting process, Soil Science and Plant Nutrition. 25. 197-208.

SunTHEIM, L. \& MATZEL, W. 1985. Determination of plant-available phosphorus in soils by continuous water extraction. Food and Agriculture Organization of the United Nations. 29. 451-456.

The Composting Association, 2001. Large-Scale Composting. A practical manual for the UK.

The U. S. Composting Council, 1997. Respirometry 9. In: Test Methods for the Examination of Composting and Compost. (Eds.: LeEge, P. B. \& Thompson, H.) 165-194. The U.S. Composting Council. Bethesda, MD. USA.

TIQUiA S. M., 1996. Further Composting of Pig manure from the Pig-on-litter (POL) System in Hong-Kong. Ph.D. Thesis. The University of Hong Kong. 475.

TIQUIA, S. M., 2002. Evaluation of organic matter and nutrient composition of partially decomposed and composed spent pig litter. Environmental Technology. 24. 97101.

Tittarelli, F., Trinchera, A., Intrigliolo, F. \& Benedetti, A., 2002. Evaluation of organic matter stability during the composting process of agroindustrial wastes. In: Microbiology of Composting. (Es.: InSAM, H., RidDECH, N. \& KLAMMER, S.) 397404. Springer. Heidelberg. Germany.

TÖRÖK L., 1959. Adatok a komposztok érlelésénél lejátszódó folyamatok ismeretéhez. Agrokémia és Talajtan. 8. 351-366.

Usui, T., ShoJI, A. \& YusA, M., 1985. Measuring for compost maturity: A test for oxygen consumption. In: Managing Sludge by Composting, (Eds.: The Staff of Biocycle) 226-231. JG Press. Emmaus. USA.

VAN DER PAAUW, V., 1969. Entwicklung und Verwertung einer neuen Wasserextraktionsmethode fur die Bestimmung der pflanzenaufnehmbaren Phosphorsaure. Food and Agriculture Organization of the United Nations. 23/11. 102-109.

WEBSTER's UnABRIDGED DictionARY OF THE ENGLISH LANGUAGE (2001)

WEPPEN P., 2002. Determining Compost maturity: Evaluation of Analytical properties Compost, Science and Utilization. 10. (1) 6-15.

Wong, J. W. C., FANG, LI K. \& Su, M., 2001. Toxicity evaluation of sewage sludges in Hong Kong. Environment International. 27. (5) 373-380.

WonG, M. H., 1985. Phytotoxicity of refuse compost during the process of maturation. Environmental Pollution Series A. 37. (2) 159-174. 
Zmora-Nahum, S., Markovitch, O., TARChitzky, J. \& Chen, Y., 2005. Dissolved organic carbon (DOC) as a parameter of compost maturity. Soil Biology and Biochemistry. 37. 2109-2116.

ZuCCONI, F. \& DE BERTOLDI, M., 1987. Compost specifications for the production and characterization of compost from municipal solid wastes. In: Compost: Production, Quality and Use. (Eds.: De Bertoldi, M., Ferranti, M. P., L'Hermite, P., ZuCCONI, F.) 30-50. Elsevier. London.

Zucconi, F., Forte, M., Monaco, A. \& De Bertoldi, M., 1981a. Biological evaluation of compost maturity. Biocycle. July/Aug. 27-29.

Zucconi, F., Monaco, A., Forte, M. \& De Bertoldi, M., 1985. Phytotoxins during the stabilization of organic matter. In Composting of Agricultural and Other Wastes. (Ed.: GASSER, J. K. R.) 73-86. Elsevier Applied Science. London. UK.

Zucconi, F., PerA, A., Forte, M. \& De Bertoldi, M., 1981b. Evaluating toxicity of immature compost. Biocycle. March/April. 54-57.

Érkezett: 2015. szeptember 11. 